\title{
STYLE AND LANGUAGE IN WRITING LAWS. THE SITUATION OF THE ROMANIAN CIVIL CODE
}

\author{
Ramona Duminică, \\ University of Pitești, Lecturer, PhD, \\ Faculty of Economic Sciences and Law, Bld. Republicii, no. 71, \\ Pitesti, Romania \\ https://orcid.org/0000-0002-3416-2329 \\ *duminica.ramona@gmail.com
}

\begin{abstract}
The debates on the drafting of laws in general and codes in particular are not recent but are an eternal topic of political and legal science, which is returning with increasing force. The same topic, but each time approached for different reasons and in different contexts, which gives it a permanent topicality.

The current scientific approach addresses the traditional issue of rules regarding the style and language of drafting a normative act. The analysis does not claim an exhaustive study in the field, but represents a call for reflection, the purpose being mainly to analyze, 10 years after the entry into force of the new Romanian Civil Code, to what extent it manages to meet accessibility requirements and intelligibility. In order to be able to truly know an institution or a legal phenomenon, in order to be able to identify its vices and qualities, it is necessary to first clarify the concept itself and establish its foundations. Therefore, the first part of the study is devoted to the theoretical aspects related to legislation, codification and presentation of the rules on the style and language of normative acts. The second part of the study focuses on highlighting, by way of example, some legal norms in the current Civil Code whose intelligibility is questioned.
\end{abstract}

Keywords: enactment, drafting the law, style, normative language, codification, intelligibility of the law

\section{INTRODUCTION}

Starting from the fact that a Civil Code represents one of the fundamental normative acts of any legal order and taking into account that it is a law that regulates the most important values of a society, such as family relations, patrimony, property, movement of goods, etc., it is necessary to be characterized by stability and accessibility.

In order to ensure these objectives, it is necessary for the normative act to be drafted in a specific legal language, concise, sober, clear and precise style that excludes any ambiguity, with strict observance of grammatical and spelling rules.

The clarity and precision of the normative style is achieved by the appropriate use of words in relation to their usual meaning and by the way they are arranged in sentences and phrases, with strict observance of grammatical rules. Polysemy creates the risk of 
misunderstanding the legal message, it contradicts the requirement of clear and precise expression of legal concepts.

Unfortunately, despite all the recommendations of specialists in law, specific legislation and guidelines for its implementation, in legislative practice it is found the use of words with a certain meaning in a normative act, and in those amending or related definitions they have a different meaning or, worse, other words with a similar meaning are used. All these lead to the appearance of contradictions between the norms included in the same normative act. Such examples are also found in the new Romanian Civil Code, and some of them are the subject of this study.

The unintelligibility of a law or a set of laws impairs its effectiveness, which is reflected, in particular, in the possibility of being understood by the one who has to respect it and the one who has to apply it. Today, the citizen can understand the law only through the lawyer. He, in turn, often faces the problem of the impossibility of deciphering its meaning due to the complicated, ambiguous style in which it is written. The complexity of decision-making, the complicated procedure for drafting the law and not all the established rules and tools of law available to the lawyer-draftsman do not always ensure the guarantee of obtaining a good law (Duminică, 2012).

The law is the product of a long journey during which many actors intervene, with different titles, such as: the Prime Minister, ministers, the president or most often their collaborators, trade unions or professional organizations, etc. The project is subject to arbitration, consultations, debates. It is necessary to take into account the international and union law and also to consider the consequences of a possible review by the constitutional judge. Beyond the choices of common devaluers, a result will be obtained without verticality, confusing. For the purpose of conciliation, Parliament could also choose an ambiguous wording (Mathieu, 2010).

All these debates, although topical, are strangely very old, recurring throughout history. The same problem always appears, it is constantly changing and it does not stop reappearing: "it is an endless cycle, a sign of the inherent imperfection of any law and of continuous effort, but inefficient in ending it: the myth of the golden age, that of simple law and clear, a timeless myth, reminiscent of a distant, legendary past and sends to a hypothetical and always precarious bright future" (Malaurie, 2005).

Whether we refer to the Romanian, Italian, Spanish, Polish or French legislation, the problem is the same for all, and the countless reproaches addressed to the wording of the law, its vices are always and everywhere the same: unintelligibility, inefficiency, inadaptability.

\section{PURPOSE, MATERIALS AND METHODS}

The present study does not aim to make a general theory of the language and style of drafting a normative act, but urges a reflection on the role and functionality of the current Romanian Civil Code, raising a question to which it tries to find a possible answer: Are the clarity and precision of language and style objectives that are impossible to achieve in writing a code?

In order to achieve this goal, several methods of scientific research are combined, respectively: the logical, historical, and grammatical method, the paper falling within 
the scope of the general theory of civil law, the topic being approached mainly from the perspective of this discipline. However, the way in which the subject is treated gives the study an interdisciplinary character reflected by documentary sources belonging to various fields: general theory of law, legal sociology, constitutional law, legal linguistics, history of law, political science etc. Beyond the traditional bibliographic documentation, the paper is also based on the direct documentation through which the analysis of the language and style in which the current Civil Code was written.

\section{RESULTS AND DISCUSSION}

\section{The enactment - science, technique, art}

Towards the end of the 1960s, with the development of the social sciences in general and of legal sociology and of political science in particular, the static view of legislation limited only to the formal adoption of laws changed radically. Lawyers are becoming aware of the dynamic nature of the law.

In this context, there are concerns about the birth and development of a true science of legislation. Its essential attribution was to find coherent answers to essential questions aimed at how social, political, economic, etc. issues can be regulated through legal norms or how social reality can be influenced in a certain way through norms.

Thus, the notion of legislation began to take shape as an "active regulation", with a welldefined purpose oriented towards the idea of justice, and the effective methods of legislation were drawn, based on the "model of conscious individual actions". The legislative technique had only an auxiliary, secondary function, being considered only the concrete way to achieve the proposed objectives. Starting from here, nowadays, the legislation is considered both a science and a technique, even an art (Zlătescu, 1995).

The science of legislation appears as interdisciplinary, bringing together not only specific areas of law, but also disciplines such as sociology, political science, public policy, etc. Legislation is considered and treated as a "process", emphasizing its dynamic nature, seeking to take into account what happens before and after the decisions of the formal legislator, i.e. the body that has a democratic legitimacy. The science of legislation is inspired by papers and theories on decision-making in general and on political decision-making in particular (Pătulea, 2010).

It is said that legislation is at the same time not only science, but also technique and Art It is the art of negotiation in order to express the political will as the will of the people, representing the art of harmonizing the demands of daily life with the possibility of achieving these requirements. The elaboration of the law is the result of the compromises between desideratum and reality. At the same time, it is technical because in the construction of the law strict rules are observed regarding its form, the elaboration and adoption procedure and, last but not least, the rigor of the legal language and style is observed.

\section{Codification - a superior form of elaboration and systematization of law}

Regarding the codification, it is a superior form of the systematization of the law and one of the most important factors of legal security.

Reviewing the definitions given to codification over time, it is observed that there are 
two categories: traditional definitions, according to which the codification presupposes "the inclusion in a code (normative act with legal force of law) of legal norms belonging to the same branch of law, involving a rich activity of the legislator, of complex processing of all normative material, of removal of obsolete, obsolete norms (including habits), of filling gaps, of legislative renewal (introduction of new norms, required by the evolution of social relations), of logical ordering of the normative material and of the use of some modern means of legislative technique (the choice of the way of regulation, of the external form of regulation, of the use of the adequate means of conceptualization)" (Popa, 2020) and the proposed by specialists in formal law, according to which codification "is that superior form of legislative systematization, consisting in rare (integration) in a single act, of large scale, of several regulations in a certain field or branch of law" (Popescu\&Ţăndăreanu, 2003).

In the sense of the second category of definitions are also the provisions of Art 18 of Law $24 / 2000$ on the norms of legislative technique for the elaboration of normative acts which stipulate that "in order to systematize and concentrate the legislation, the regulations in a certain field or in a certain branch of law, subordinated to common principles, may be reunited - a unitary structure, in the form of codes".

Therefore, codification is both a form of systematization and an important component of the legislative activity, which is why the codification act (adoption of the code) is the exclusive competence of the Parliament.

Although codification is sometimes seen as a simple remedy for legislative inflation and the dispersion of sources, in which case the code itself risks being an excess, codification is the expression of a rational right based on a logical and systematic method that must allow the establishment of general principles and to provide concrete and intelligible consequences for the individual (Nadaud, 2008).

Codification is more than a sum of laws; it reflects the spirit of a system as a whole. Also, if the codification process can restore its traditional values to the law, a bright future awaits it, otherwise it will suffer the same discredit developing the predictions made some time ago: "Today, codes only suffocate us with their formulations..." (Oppetit, 1998).

From the perspective of our study, we argue that codification could remedy a number of major defects of the law and implicitly of the modern state: proliferation, accumulation, unintelligibility of rules and legislative instability. As such, codification aims to ensure better accessibility of legislation, in accordance with the principle of legal certainty, allowing the creation of a single document in a field of law, which brings together the scattered rules to make them coherent and accessible, based on a plan coherent. This plan makes it possible to clarify the rules on codification, to update them by repealing obsolete, incompatible or unconstitutional texts, and to adapt them to Union or international rules.

In the Romanian law, although there were codes before 1864 (for example, the Caragea Code and the Calimach Code in 1831), still in the history of our law, the Romanian Civil Code, elaborated in 1864 during the reign of Alexandru Ioan Cuza and entered effective December 1,1865 . The value of this code is indisputable, as it includes all the rules and institutions of private law. This value is given not only by its content, but also by the form of its wording and the language used. Basically, in Romania only after the adoption of 
this code can we talk about the birth of a legal language (Predescu, 2006). In those times, neologisms were used in its drafting and foreign terms in the legal field were adapted to the Romanian language, given that the main source of its conception was the French Civil Code of 1804. Finally, it resulted in a modern and accessible normative act, written in a simple and precise style.

This code remains in history as a model of regulation, a proven aspect and the duration of its application, respectively from 1865 until 2011 when the new Romanian Civil Code came into force. Although during the communist regime, important parts of the code were repealed, became inapplicable, were supplemented, amended, yet it survived those times, and after the Revolution of December 1989, regained its place as a basic normative act of the Romanian civil law.

The transformations undergone by the Romanian society in the years following the revolution, the integration in the European Union, the assumption of the obligation of legislative harmonization, as well as the impossibility of the 1864 code to regulate the new social, cultural, technical-scientific and economic values appeared as a result of natural evolution of the social realities in our country are some considerations that imposed the need to elaborate a new Civil Code. Therefore, in 2009, after the long efforts of Romanian lawyers to modernize the civil law, the Romanian Parliament adopted by Law no. 287/2009 the new Civil Code, entered into force on October 1, 2011. It was intended that this new code be a modern tool for regulating the fundamental aspects of individual and social existence, including all provisions regarding persons, family relations, relations trade relations and even private international law relations, thus promoting a monistic conception in the regulation of private law relations. This concept is also promoted by other European countries such as France, Switzerland, the Netherlands or Italy. As stated in the explanatory memorandum, one of the main sources of inspiration or one of the models used for the elaboration of the new Romanian Civil Code is the Civil Code of the province of Quebec in Canada. Although the Quebecoise Civil Code is indeed the most recent of the codes of the other civil law states and extremely well elaborated, being the result of over 50 years of intense work, we still consider this option of the Romanian legislator uninspired, based primarily on the novelty argument because, as we have already argued in other studies (Tabacu\&Duminică, 2012), it is obvious that this model does not include the regulations that must be found in the case of a unitary state, as is the case in Romania. While the legislation of a province is, of course, complemented by existing legislation at the federal level, the situation is not the same for unitary states.

Moreover, the mere copying of provisions, as certain institutions are sometimes illustrated in the new Civil Code, does not amount to a real codification activity that should start from a solid, scientific research of the social realities existing at the level of a society. There is a risk that the way in which certain institutions are regulated may prove not to correspond to the environment where their implementation is desired, which may lead to the lack of finality of those rules. If indeed the Civil Code of 1864, considered to be a faithful copy of Napoleon's civil code, proved its effectiveness over time, it remains to be seen whether such an approach to codification is equally effective in the current society. 


\section{Clarity and precision of language and style - objectives impossible to achieve in drafting a normative act? The situation of the Romanian Civil Code}

Both history and linguistics attest to the fact that the intelligibility of laws is a goal that has never been achieved but has always been pursued.

Two examples of this constant are sufficient to prove this: the Roman Law of the Twelve Tables and the Drafting of Customs in France. In the $5^{\text {th }}$ century BC, the plebs fought and finally obtained the drafting and publication of the Law of the Twelve Tables, necessary to defeat the arbitrary omnipotence of the patrician priests. One notices here the complex importance of understanding the law, which is not only a technical reality, a knowledge of the law, a certainty and a simplification characteristic of it, but a political problem above all. The emancipation of the plebs thanks to the Law of the Twelve Tables was a remarkable event and probably one of the most important in the history of Rome.

However, like any normative act, the Law of the Twelve Tables was eroded by the passage of time and a huge body of norms was slowly and inexorably added to it, turning it into a difficult law to understand, so much so that in the $6^{\text {th }}$ century AD. Justinian undertook the drafting of the Digests, which he intensely promoted: "Both the rich and the poor can buy [the laws] for a few pennies and obtain for nothing the essence of wisdom". Again, as in the case of the Law of the Twelve Tables, the simplification of laws is part of a political plan to make the law more accessible to the people. Immediately, criticism also appeared, Montesquieu pointing out that "The Law of the Twelve Tables is a model of precision; the children learned it by he Art Justinian's new laws are so vague that they needed to be shortened". The same happened in the $15^{\text {th }}$ and $16^{\text {th }}$ centuries in France when King Charles VII ordered the customs to be drafted by the ordinance of Montil-lès-Tours, because their existence could not be proved. After the customs were drafted, history repeated itself: the law expanded, then it was simplified by the Civil Code, then it developed again. The Twelve Tables, the efforts of Justinian and Charles VII, the Civil Code, the codification of constant law, all these examples show us that the law always becomes unintelligible (Malaurie, 2005).

The history of law therefore easily demonstrates that the simplification of legal norms is a desideratum that seems intangible, but to which it must constantly strive. In contemporary society, doctrinal debates (Deleanu, 2011; Duminică, 2012) are just as intense. Recently, it was substantiated in a specialized paper that "the effectiveness of the law is closely related to its comprehensibility. The law is understandable to the recipient only if it serves their communicative needs. The coherence of the law is one of the conditions of the intelligible law" (Osiejewicz, 2020).

Therefore, through the combined effort of doctrinaires and practitioners, this universal and eternal aspiration of the intelligibility of the law has today become an obligation for the legislator and a "human right".

\subsection{The language of the legislator and the style of drafting normative acts}

In the activity of elaboration of the normative acts, after the establishment of the legal concepts and, mainly of the legal rules, follows the transposition in words, the effective drafting of the law. At this stage, it is essential to identify the word and the clear, coherent, simple formula for expressing the rules of law. The word and the formula of expression thus 
constitute the basic tools, absolutely necessary for the communication of the notions, norms and legal reasonings.

Starting with the theological phase of the law, passing through Antiquity, through Roman law and reaching contemporaneity, the veneration of the word was maintained, the word reflecting the essence of the act, people believing in the law, and for most the law meaning word. From this perspective, the normative act expresses the word of the legislator, through which the rights and obligations of the citizens are brought to the knowledge of the citizens. Given the addressee of the rule, it is necessary that the drafting of the legislative text be subordinated to the use of words with wide circulation, accessible to the whole population, the use of words in their proper sense, and the use of technical terms should refer only to those regulations which cannot find a correspondent in the current language.

In general, the drafting of the law involves the transposition in written text of the ideas that make up the substance of the regulation. The correct wording of the text is a fundamental condition for maintaining - in the application activity - the authenticity of the intended concept and solutions. The text of the law is considered to be "the outer garment of the will of the legislator", the form of expression of a thought, and a thought can be received correctly only through a clear and precise message. Between the background of the law and its form of textual expression there is a dialectical relationship, a relationship of mutual involvement. The text is the expression of the legislator's thought, and the background, in turn, cannot exist outside an expression, the text of the law being the means of communication that expresses the will of the legislator (Mrejeru, 1979).

As a rule, as it results from the above, it is considered that the legislative language is the expression of the legislator's thinking as if it is or could be contained or reflected entirely in the language. Or, thinking is always much deeper than language, and the word, no matter how well chosen, cannot have the brilliance of thought.

Legal language is not only an external formula of the legislator's decisions, but it is a structured language, with its internal dynamics, with its own content and form. The problem of language that the legislator has to solve is thus extremely complex. The possibility of translating the nuances of thought into a clear text that aims to be applied by all in the same way seems an almost unattainable goal or extremely difficult to achieve. In order to obtain this desideratum, the rules of legal linguistics are usually used.

Thus, linguists analyzed the discourse as that of a single author "ME", pronounced in a non-neutral place "HERE", currently pronounced "NOW". However, the keys to the analysis of discourse considered as the expression of the thinking of the one who utters it, which contemporary linguistics provides us, are partially unsuited to the legislative discourse (Richevaux, 2002).

The conditions for drafting the legislative discourse do not allow the application of this scheme and explain, in large part, the difficulties encountered by a text of law, faced with a practice that does not always receive the same message as the one issued by the legislator who drafted the law to be applied. First of all, the legislative discourse is related to a pluralistic thinking, there are several authors with different thoughts who do not always meet and who often do not even really try this. Legislative activity is often presented as hurdle-race in which everyone seeks more to prevail than to participate in the elaboration 
of a joint work. This makes the synthesis that will have to result from the deliberation more difficult to obtain and greatly relativizes the uniqueness of the thinking of the legislator about which the jurists discuss.

As such, referring to the conditions of drafting the law, the thinking of the legislator becomes plural. It is the result of a deliberation, which often takes the form of confrontations, which damages the uniqueness of the discourse, so that sometimes one can speak of a pluripaternity of the law, which does not allow to reach automatically a text characterized by clarity, although one of the virtues of the parliamentary debate is to allow the improvement of the technical quality of the text precisely due to the debate (Richevaux, 2002).

These are just a few reasons why today's law is characterized by instability and unintelligibility.

Distinct from language, in the specialized literature is treated the normative style defined as "the totality of the artifices and the modalities that are the basis for the drafting of normative acts" (Vida, 2012).

Although there were opinions according to which there would be a plurality of styles, one could thus speak a style specific to private-civil, commercial, private international law - with certain particularities in the normative acts regarding labor relations and social protection, another style in criminal law, and finally, another in administrative law (Zlătescu, 1995), as far as we are concerned, we consider, taking into account the provisions of Art 36 of Law 24/2000 on the norms of legislative technique for the elaboration of normative acts suggestively entitled - "the style of normative acts" - that we are in the presence of a single style proper to normative acts, regardless of the name (law, code, ordinance or Government decision).

\subsection{Legal provisions regarding the style and language of drafting a normative act and their observance in drafting the Romanian Civil Code}

Law 24/2000 dedicates chapter IV, entitled "Drafting of normative acts", to the rules that must be observed by the drafter of the law in the elaboration of any normative act. Thus, Art 35 stipulates that it is necessary to ensure a logical succession of the envisaged legislative solutions and to achieve an internal harmony of the normative act so that the drafting of the draft text is preceded by drawing up a plan for grouping ideas according to the connections and the natural relationship between them, within the general conception of regulation.

Regarding the drafting style, the Romanian legislator expressly provides that normative acts must be drafted in a specific normative language and legal, concise, sober, clear and precise style, which excludes any ambiguity, with strict observance of grammatical and spelling rules. At the same time, it is forbidden to use of neologisms, if there is a synonym that is widespread in Romanian. In cases where the use of foreign terms and expressions is required, their correspondent in Romanian will join, as appropriate. The writing of the texts is done by using the words in their current meaning from the modern Romanian language, avoiding regionalisms. The wording is subject to the desire of the recipients to easily understand the text.

Also, Art 37 of the same law establishes that in "normative language the same notions are expressed only by the same terms. In the event that a notion or term is not established or 
may have different meanings, its meaning in context is established by the normative act that establishes them, within the general provisions or in an annex intended for the lexicon, and becomes mandatory for normative acts from the same matter".

Regarding the expression of the normative content, the legislator mentions the need for the text of the articles to have a dispositive character and to present the established norm without explanations or justifications. Usually, in drafting the normative act, verbs are used in the present tense, the affirmative form, to emphasize the imperative nature of that provision, and the use of explanations by interpretative rules is allowed only insofar as they are strictly necessary for understanding the text.

Last but not least, the legislative text must be clearly, fluently and intelligibly formulated, without syntactic difficulties and obscure or equivocal passages. The use of emotionally charged terms is not allowed. The form and aesthetics of the expression must not prejudice the legal style, the precision and the clarity of the provisions.

Although these rules exist and efforts have been made to improve the language and normative style, in practice we still quite often find unintelligible provisions, rules that give rise to contradictory interpretations, unclear and therefore lacking much desired accessibility. Unfortunately, we also find such examples in the current Civil Code.

It is true that the legislator of the Romanian Civil Code in force has made real progress in terms of language and style used, removed the archaisms that made it difficult to understand the texts of the previous code, but on the other hand, by redefining certain traditional institutions of civil law, has again fallen into the trap of lack of clarity. Such an example is the definition given to a fundamental institution of civil law, the property, a definition that has a predominantly technical character, difficult to understand for the simple litigant, the Code establishing by Art 555 Para 1 that "private property is the right of the owner to own, use and dispose of an asset exclusively, absolutely and perpetually, within the limits established by law".

Although the legislator expressly used the notion of private property, in reality, he sought to express the definition of property in general, given that Art 858 of the Civil Code no longer defines public property by reference to the attributes it confers on the holder, but by reference to the right to property in general and by showing its holders and its object: "Public property is the property right that belongs to the state or to an administrativeterritorial unit over the goods that, by their nature or by the declaration of the law, are of use or of public interest, provided that they are acquired by one of the means provided by law".

Another source of ambiguity of the legal language used in the Civil Code is polysemy, that quality of a word to have several meanings. Although the legal language must be univocal, it is still characterized by the frequency of polysemy. This aspect also has a positive side because the polysemy of words ensures the longevity of legal norms and opens the way for legal interpretation.

If polysemy is accepted as a feature of legislative language, however, synonymy must not be accepted. In this sense, the provisions of Art 37 of Law no. 24/2000 regarding the norms of legislative technique establish the obligation to express the same notion only through the same terms. Unfortunately, the reality of legislative practice is different. An example of 
terminological inconsistency is identified in the Civil Code in the provisions on goods. The code defines by Art 535 goods as things, corporeal or intangible, which constitute the object of a patrimonial right.

The use of the term "good" is debatable because it itself reveals the corporeality, and the notion of incorporeal good clearly contains a contradiction between the two terms (Chelaru, 2014). Moreover, the legislator sometimes uses the notion of "things", other times that of "goods" as an object of patrimonial rights.

For example, it uses with the same meaning in Art 563 Para (4) of the Civil Code, when the term of "good", when the term of "things", to designate the same reality: "The court decision admitting the action in claim filed against the possessor is also opposable to the one holding the good for the owner, being enforceable directly against him. The court decision admitting the action in claim against the holder of the good for the possessor is not opposable to the possessor, if he has not been introduced in the case". The same terminological inconsistency is identified in Art 941 of the Civil Code, in the content of which is used when the phrase of mobile good, which is not defined anywhere in the code, when the phrase of movable property.

To eliminate these ambiguities, we consider that it was preferable to use instead of the word "thing" in the definition of the good, the phrase "economic value" or asset.

Another situation - a source of ambiguity, vagueness and intelligibility of the text of the current code - is found in the fact that the classic notion of "violation" of the law is often replaced by the legislator with a notion such as "infringement" of the law, term which is sometimes synonymous with "violation" of the law in the Code, and sometimes not. For example, in Art 253 C.civ. the expression "non-patrimonial rights that have been harmed or threatened" is used, and not violated or harmed, and in Art 255 Para (6) C.civ. there is talk of "... protection of the violated non-patrimonial right", and not of the right that has been harmed. The explanation found in the literature for such situations was that the texts were written by different authors and were not correlated, which is inadmissible from the perspective of the legislative technique norms (Dănișor, Badea, 2015).

This diversity of wording generates controversy and affects the clarity of language and normative style. At the same time, this diversity "introduces in the legal terminology distinctions, either artificial or inaccurate, affecting the precision of some of the normative statements" (Neculaescu, 2010).

Considering that the term "infringement" of the right is a polysemantic one, it was preferable to avoid its use by the legislator or, if it was chosen, it was necessary to define it in advance, as expressly stated in Art 37 of Law 24/2000 on the norms of legislative technique.

I have illustrated above only a few examples of legal norms from the content of the current Civil Code whose intelligibility is questioned, but the examples can continue. It is equally true that, fortunately, this Code nevertheless responds to the need for a modern legislative framework, representing a coherent response to the need to reform the institutions and fundamental mechanisms of Romanian civil law. 


\section{CONCLUSIONS}

Although subordinated to Union and international law, subject to competition from other rules based on other forms of legitimacy, often affected by lack of predictability and intelligibility, the Civil Code remains the irreplaceable expression of the general will, the expression of democracy and the main formal source of Romanian civil law. Taking into account the special social impact it has on the subjects of law by regulating their conduct, the activity of elaborating a code is extremely complex and implies a great political, legal and even moral responsibility on the part of the legislator.

Regardless of the legislative technique, the role of control and evaluation mechanisms in the elaboration of the law, the bodies involved in the elaboration of legal norms must have as a desideratum towards which at least three intertwining aspects tend: the legal security of the person, simplification and efficiency of rules.

As we have shown in the study, at the level of Romanian legislation, the rules meant to ensure the understanding of the text of the law by the litigant are well outlined, only that, unfortunately, they are not observed. The clarity of the law is vital for the successful exercise of the citizen's rights, and in order to achieve this objective, the correct application of the norms of legislative technique has a decisive role, as they support the increase of the accessibility of the normative acts.

Capitalizing on the literature and the practice of drafting the new Civil Code, critically analyzing the language and style in which it was written, we hope that this study contributes to completing scientific research in this field, joining other works aimed at increasing the quality of legislation, it can be useful for all participants in the law-making process.

\section{REFERENCES}

Dănișor, D. D., Badea S. (2015) Polisemie și ambiguitate în limbajul Codului civil. Revista de Științe Juridice, 26 (1), 134-144.

Deleanu, I. (2011) Accesibilitatea şi previzibilitatea legii în jurisprudenţa Curţii Europene a Drepturilor Omului şi a Curţii Constituţionale române. Revista Dreptul, 8, 52-82.

Duminică, R. (2012) Intelligibility of the Laws - a Desideratum Difficult to Achieve by the Romanian Legislator. In the volume International Scientific Conference: Logos, Universality, Mentality, Education, Novelty. Iaşi: Lumen, 169-187.

Malaurie, Ph. (2005) L'intelligibilité des lois. Pouvoirs - Revue francaise d'etudes constitutionnelles et politiques, 114, 131-137.

Mathieu, B. (2010) La loi. Paris: Dalloz, 144 p.

Mrejeru, I. (1979) Tehnica legislativă. Bucharest: Romanian Academy Press, 228 p.

Nadaud, S. (2008) Codifier le droit civil européen. Bruxelles: Larcier, 464 p.

Neculaescu, S. (2010) Noul Cod civil, între tradiție și modernitate în ceea ce privește terminologia juridică normativă. Revista Dreptul, 12, 11-41.

Oppetit, B. (1998) Essai sur la codification. Paris: Presses Universitaires de France, 96 p.

Osiejewicz, J. (2020) Transnational Legal Communication: Towards Comprehensible and Consistent Law.

Found Sci 25, 441-475. https://doi.org/10.1007/s10699-020-09655-3

Pătulea, V. (2010) Tratat de management juridic şi jurisdicţional. Bucharest: I.R.D.0., 984 p. 
Popa, N., (2020) Teoria generală a dreptului. Bucharest: C. H. Beck, 296 p.

Popescu, S. \& Țăndăreanu, V. (2003) Probleme actuale ale tehnicii legislative. Bucharest:

Lumina Lex, $544 \mathrm{p}$.

Predescu, I. (2006) Elogiu Codului Civil. Revista de Științe Juridice, 1, 7-9.

Richevaux, M. (2002) Limbajul legii și legile limbajului. Buletin de informare legislativă, 22-31.

Tabacu, A. \& Duminică, R. (2012) The Fiduciary Contract and the Administration of the Goods of Another Person in the New Civil Code. A Comparative Outlook. Journal of Legal Studies. Supplementary Issue 3 (1-2), 171-189.

Vida, I. (2012) Legistică formală. Introducere în tehnica şi procedura legislativă, $5^{\text {th }}$ Edition. Bucharest: Universul Juridic, $224 \mathrm{p}$.

Zlătescu, V. D. (1995) Introducere în legistica formală. Bucharest: Rompit, 170 p. 